Ambiente \& Água - An Interdisciplinary Journal of Applied Science
ISSN 1980-993X - doi:10.4136/1980-993X
www.ambi-agua.net
E-mail: ambi.agua@gmail.com

\title{
Analysis of the long-term effects of groundwater extraction on the water balance in part of the Urucuia Aquifer System in Bahia - Brazil
}

\author{
ARTICLES doi:10.4136/ambi-agua.2390 \\ Received: 10 Mar. 2019; Accepted: 15 Oct. 2019 \\ Leanize Teixeira Oliveira ${ }^{1,2 *}$; Harald Klammler $^{3}$ KD; $^{(1)}$ \\ Luiz Rogério Bastos Leal ${ }^{3}$; ; Eduardo Moussale Grissolia ${ }^{4}$ (iD \\ ${ }^{1}$ Gerência de Hidrologia e Gestão Territorial. Serviço Geológico do Brasil (CPRM), \\ Avenida Ulysses Guimarães, $n^{\circ}$ 2862, CEP: 41213-000, Salvador, BA, Brazil \\ ${ }^{2}$ Departamento de Geologia. Instituto Federal da Bahia (IFBA), Rua Emídio Santos, s/n, \\ CEP: 40301-015, Salvador, BA, Brazil \\ ${ }^{3}$ Instituto de Geociências. Universidade Federal da Bahia (UFBA), Rua Barão de Geremoabo, s/n, \\ CEP: 40210-340, Salvador, BA, Brazil. E-mail: haki@gmx.at, lrogerio@ufba.br \\ ${ }^{4}$ Departamento de Recursos Minerais. Serviço Geológico do Brasil (CPRM), Avenida Ulysses Guimarães, \\ n² 2862, CEP: 41213-000, Salvador, BA, Brazil. E-mail: eduardo.grissolia@cprm.gov.br \\ "Corresponding author. E-mail: leanize.oliveira@cprm.gov.br
}

\begin{abstract}
In agricultural regions where there is insufficient rainwater for cultivation, understanding the dynamics of surface water and groundwater is critical to assess the impact of increased well pumping on the water balance. The western region of the state of Bahia-Brazil, the largest area of agribusiness in the state, has experienced progressive occupation since the 1980s, resulting in pressure on water resources - mainly after the introduction of irrigation - and conflicts among water users. This study analyzed the effects of groundwater extraction by wells in a portion of the Urucuia Aquifer System. The methodology used was the simulation of groundwater flow in steady-state for three scenarios: i) without withdrawal of water by pumping wells; (ii) with current withdrawal rates; and (iii) with $60 \%$ additional extraction. After defining well production rates from field surveys $\left(4.6 \mathrm{~m}^{3} \mathrm{~s}^{-1}\right)$ and modeling of the aquifer base geometry (maximum thickness of $535 \mathrm{~m}$ ), the steady-state models with and without pumping show that, in the long term, groundwater storage decreases by $2 \mathrm{~km}^{3}(0.8 \mathrm{~m}$ on average in the aquifer) without interference in the regional flow direction. The mass balance shows that the base flow of the main rivers is reduced by approximately $6 \%$ after current groundwater extraction and an additional $2.5 \%$ after additional extraction. The results point to a greater impact on surface water caused by a reduction in groundwater storage and related river base flow. This indicates the importance of maintaining and expanding the groundwater-level monitoring network.
\end{abstract}

Keywords: base flow, numerical flow simulation, steady state.

\section{Análise dos efeitos a longo prazo da extração de água subterrânea sobre o balanço hídrico em parte do Sistema Aquífero Urucuia na Bahia - Brasil}

\section{RESUMO}

Em regiões agrícolas onde há insuficiência de chuva para o cultivo, entender a dinâmica das águas, superficiais e subterrâneas, é fundamental para avaliar o impacto do crescente 
bombeio de poços sobre o balanço hídrico. O Oeste do estado da Bahia-Brasil, maior área de agronegócio do estado, experimenta uma progressiva ocupação a partir da década de 80, ocasionando pressão sobre os recursos hídricos, principalmente após a introdução da irrigação, e já apresentando conflitos entre usuários das águas. Objetivou-se neste trabalho, analisar os efeitos da extração de águas subterrâneas por poços em uma porção do Sistema aquífero Urucuia. A metodologia utilizada foi a simulação de fluxo hídrico subterrâneo em regime estacionário para três cenários: i) sem bombeio; ii) com bombeio atual e; iii) com $60 \%$ a mais de extração por poços. Após definição das vazões de produção dos poços atuais $\left(4,6 \mathrm{~m}^{3} \mathrm{~s}^{-1}\right) \mathrm{e}$ da modelagem da geometria da base do aquífero (espessura máxima de $535 \mathrm{~m}$ ), os modelos estacionários sem bombeio e com bombeio mostram que, a longo prazo, o armazenamento de água subterrânea diminui em $2 \mathrm{~km}^{3}$ (rebaixamento médio no aquífero de $0.8 \mathrm{~m}$ ) sem interferências na direção de fluxo regional. O balanço de massa mostra que o fluxo de base dos rios principais é reduzido em aproximadamente $6 \%$ após a extração de água subterrânea atual e mais 2,5\% após acréscimo de extração. Resultados apontam para um impacto maior sobre rios, causado por uma redução no armazenamento e fluxo de base. Os estudos indicam a importância de manter e expandir a rede de monitoramento dos níveis d’água.

Palavras-chave: fluxo de base, regime estacionário, simulação numérica de fluxo.

\section{INTRODUCTION}

Demand for fresh water is growing all over the world. It is estimated that agricultural use accounts for about $70 \%$ of the water used on the planet and that this number will rise by $19 \%$ over the next 50 years (UNESCO, 2012). The intensive use of water in rural areas has been increasing due to pressure for food crops and the production of other agricultural goods, such as wood from reforestation and rubber. Brazil is the world's second largest exporter of food, and water consumption for irrigation represents $68.4 \%$ of total demand (ANA, 2018). Currently, the introduction of new agricultural techniques has contributed to increasing productivity in the field, but despite the technological innovations the success of agricultural activities is closely linked to the supply of water. Irrigated agriculture is the largest component in regional water demand in the country and the potential for expansion is believed to be 10 times greater than current usage (Ferrarini et al., 2016). In agricultural areas, groundwater (exploited by wells) and surface water together are the sources of supply for small, medium and large irrigation systems. In this context, it is relevant to monitor the demands of water and the states of aquifers in order to detect and avoid harmful effects caused by sustained pumping, like severe groundwater depletion, as already reported for various parts of the world (Werner et al., 2013).

Consequently, in investigating the dynamics of groundwater flows of a given region, it is relevant to measure the changes between the natural conditions and the post-pumping conditions, thus enabling the evaluation of changes in the environment.

In Brazil, the large national agricultural frontier known as MATOPIBA (acronym formed by the initial two letters of the states Maranhão, Tocantins, Piauí and Bahia) illustrates the issue of sustainable use of water resources and agricultural occupation (Miranda et al., 2014; Bragança, 2018). In the portion of MATOPIBA contained in the western region of Bahia, an expanding agricultural frontier has emerged since the middle of the 1980s (Oliveira, 2015). It accounts for one-third of all agricultural wealth in Bahia (AIBA, 2018). Mechanized agriculture occurs in this region, and is often irrigated using superficial and subterranean water resources (Santos, 2016; Pousa et al., 2019).

In the western region of the state of Bahia, this form of cultivation is present in the flat areas of the Cerrado that border streams and rivers. In these areas, due to the occurrence of 
rainfall in well-defined seasons, the development of the rainfed or irrigated cultivation is boosting agribusiness. The water resources that meet this demand come from rainfall, river waters and the Urucuia aquifer (which has regional dimensions and extends from the south of Piauí to the north of Minas Gerais), and are used for irrigation, the animal and human water supply, and to compose the syrup for application of pesticides to the crops. These demands lead to a growing concern about the sustainability of the system, and have recently generated conflicts and manifestations among the local population, the agricultural sector and the energy sector (due to the installation of small hydroelectric plants) (Saraiva, 2017; Nogueira, 2018).

The understanding of complex water systems, with temporal and spatial particularities, requires the use of numerical modeling to simulate groundwater flow, especially when the studied aquifer has regional dimensions (Anderson and Woessner, 1992). It is a widely applied methodological tool, as it allows the characterization and understanding of the dynamics of water circulation in the environment to simulate predictive scenarios of exploitation, and to evaluate water availability. Results can be very useful in assisting decision-makers and may help to settle disputes between water users. It is also known (Freeze and Cherry, 1979) that the effects of pumping for short periods are more dependent on the physical properties of the aquifer and the geometry of the well field, while for long term analyses, the nature of the boundary conditions are more relevant. The numerical modeling used in hydrogeological studies can investigate both aspects and consists of representing the real world in the form of idealized conceptual models where computational packages allow the resolution of differential equations of groundwater flow. This results in the calculation of hydraulic heads in several points of the modeled area in one-, two- or three-dimensions. There are many studies using such numerical models to evaluate groundwater abstraction and its effects on river-aquifer interaction in different countries (Sanz et al., 2011; Haque et al., 2012; Switzman et al., 2015; Sahoo and Jha, 2017).

In the case of the Urucuia aquifer, some work has already been carried out in order to understand the groundwater flow dynamics from field data, using a classical methodology of hydrogeological study and geophysical surveys (SRH, 2003; CPRM, 2008; Gaspar and Campos, 2007). The main contributions are hydrogeological characterization in terms of potentiometric maps, surveys of hydraulic parameters and qualitative aspects of the water. Numerical models have also been applied, targeting questions in specific portions of it. Schuster (2003a; 2003b) modeled the Cachorro and Fêmeas River Basins, aiming to define granting criteria, using the finite difference method (FDM) PMWIN (Processing MODFLOW for Windows) in a stationary and transient regime, and productive wells as observation wells. In the same way, Schuster et al. (2010) only considered the transient regime in the Cachorro River Basin. Engelbrecht and Chang (2015) and Gonçalves and Chang (2017) modeled the Corrente and Grande River Basins using the stationary finite element method (FEM) FEFLOW, but without considering the wells operating in the area.

Although studies have been carried out on the hydrogeology of our study region, some important aspects of the understanding of the potential and availability of water resources have not yet been investigated or are controversial, such as the discharge data of pumping wells, thickness of the aquifer and the hydraulic interaction between surface water and groundwater, which is highly important for the riverside population and for agribusiness.

This work analyzes the effects of well pumping on the dynamics and storage of groundwater and surface water in a regionally important part of the Urucuia aquifer. The methodology consisted of: i) surveying the rate of pumping groundwater from the wells registered in the study area; ii) modeling the geometry of the aquifer in light of the current data; and iii) numerical modeling in steady state, using Visual Modflow, for three scenarios: natural environment without pumping; with pumping under current conditions; and with hypothetical pumping, including a $60 \%$ increase in the flow rate extracted in 60 new wells. Results include 
the calibrated aquifer properties and the long-term effects of pumping on groundwater storage, in addition to the quantification of pumping interference to the base flow of the rivers.

\section{MATERIALS AND METHODS}

\subsection{Study area}

The study area is located in the extreme west of the state of Bahia - Brazil and covers part of the Corrente River Basin (Éguas, Arrojado and Formoso sub-basins), which is a tributary of the left margin of the São Francisco River, the main river of the state of Bahia. It is bounded to the north, south and west by topographic dividers of the basins, and to the east by outcrop limit of the Urucuia Group. It is located between the coordinates $44^{\circ} 08^{\prime} 18^{\prime \prime}$ and $46^{\circ} 17^{\prime} 52^{\prime \prime} \mathrm{W}$ and $14^{\circ} 55^{\prime} 16^{\prime \prime}$ and $13^{\circ} 14^{\prime} 54^{\prime \prime} \mathrm{S}$, comprising a geographical area of $19,596 \mathrm{~km}^{2}$ and covering the rural areas of the municipalities of Jaborandi and, partially, Correntina, Cocos and Coribe. The region represents about $16 \%$ of the entire outcrop area of the Urucuia aquifer that occurs along the Sanfranciscana Basin (Figure 1). The modeling area was defined based on the need to match known boundary conditions of the modeling domain, undergoing changes in the Eastern and Western margins, as described in more detail in Item 2.4.
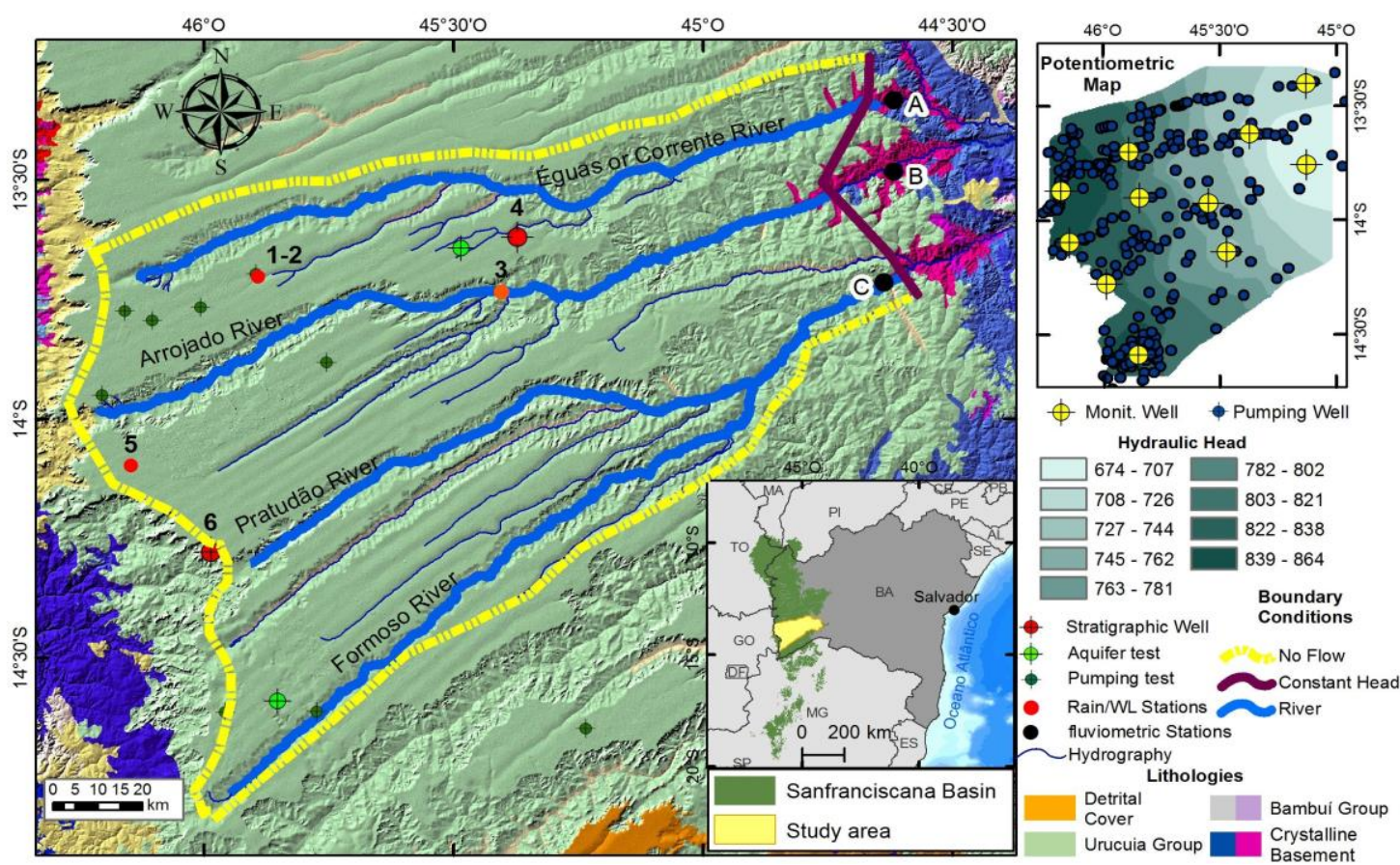

Figure 1. Shaded relief geological map of the study area (adapted from CPRM, 2008), highlighting the area modeled with boundary conditions, climatological and groundwater observation stations, and stratigraphic wells. Inset is a map of the extent of occurrence of the Urucuia aquifer in the Sanfranciscana Basin. Potentiometric surface map with distribution of pumping and observation wells.

The Urucuia aquifer is formed by very fine, fine and medium sandstones, well selected, with lenses of conglomerates in any stratigraphic position, and there are still discontinuous and dispersed silicified levels of the fluvial-eolian environment in the Neo Cretaceous formations of the homonymous group (Campos and Dardenne, 1997). In the study area, the substrate of the Urucuia Group consists of Neoproterozoic metasediments (pelites and calcarenites) of the Bambuí Group, Archaean/Proterozoic granitic-gneiss rocks and, according to Campos and Dardenne (1994), glaciogenic sediments of Permian-Carboniferous Santa Fé Group. In two stratigraphic wells made by the Geological Survey of Brazil (GSB) in 2013-2014 (CPRM 
personal communication, 2013), the Urucuia Aquifer System (UAS) has a thickness of $206 \mathrm{~m}$ on the western border and $418 \mathrm{~m}$ in the north central portion, settling on the Bambuí Group (the geological mapping applied is on a scale of 1: 250,000, Figure 1).

The hydrodynamic parameters of Urucuia were obtained from aquifer tests performed by CPRM (2008) in two distinct points in the Éguas and Formoso River Basins, and the values found were: effective porosities of $14 \%$ and $17 \%$, transmissivities of $4.1 \times 10^{-2} \mathrm{~m}^{2} \mathrm{~s}^{-1}$ and $1.6 \times 10^{-}$ ${ }^{2} \mathrm{~m}^{2} \mathrm{~s}^{-1}$, storage coefficients of $8.6 \times 10^{-3}$ and $4.7 \times 10^{-3}$, horizontal hydraulic conductivities of $1.7 \times 10^{-4} \mathrm{~m} \mathrm{~s}^{-1}$ and $6.9 \times 10^{-5} \mathrm{~m} \mathrm{~s}^{-1}$, vertical hydraulic conductivities of $1.4 \times 10^{-4} \mathrm{~m} \mathrm{~s}^{-1}$ and $8.1 \times 10^{-}$ ${ }^{5} \mathrm{~m} \mathrm{~s}^{-1}$. The general flow direction is from south-west to north-east; however, in the western portion, there is a groundwater divide in an approximate north-south direction, which is not coincident with the topographic divide (Figure 1). Wells monitored as of December 2015 demonstrate constant water-level declines, even after rainy periods, with magnitudes varying from 0.56 to $2.86 \mathrm{~m}$ until 2018 (Figure 2).

The climate is classified as tropical with dry winter; rainfall decreases from west to east and north to south, with values ranging from 1,200 to $1,000 \mathrm{~mm} \mathrm{year}^{-1}$, and monthly maxima occurring from November to May, while lows occur from June to October. The annual mean values of temperature and relative humidity are $24^{\circ} \mathrm{C}$ and $70 \%$, respectively.
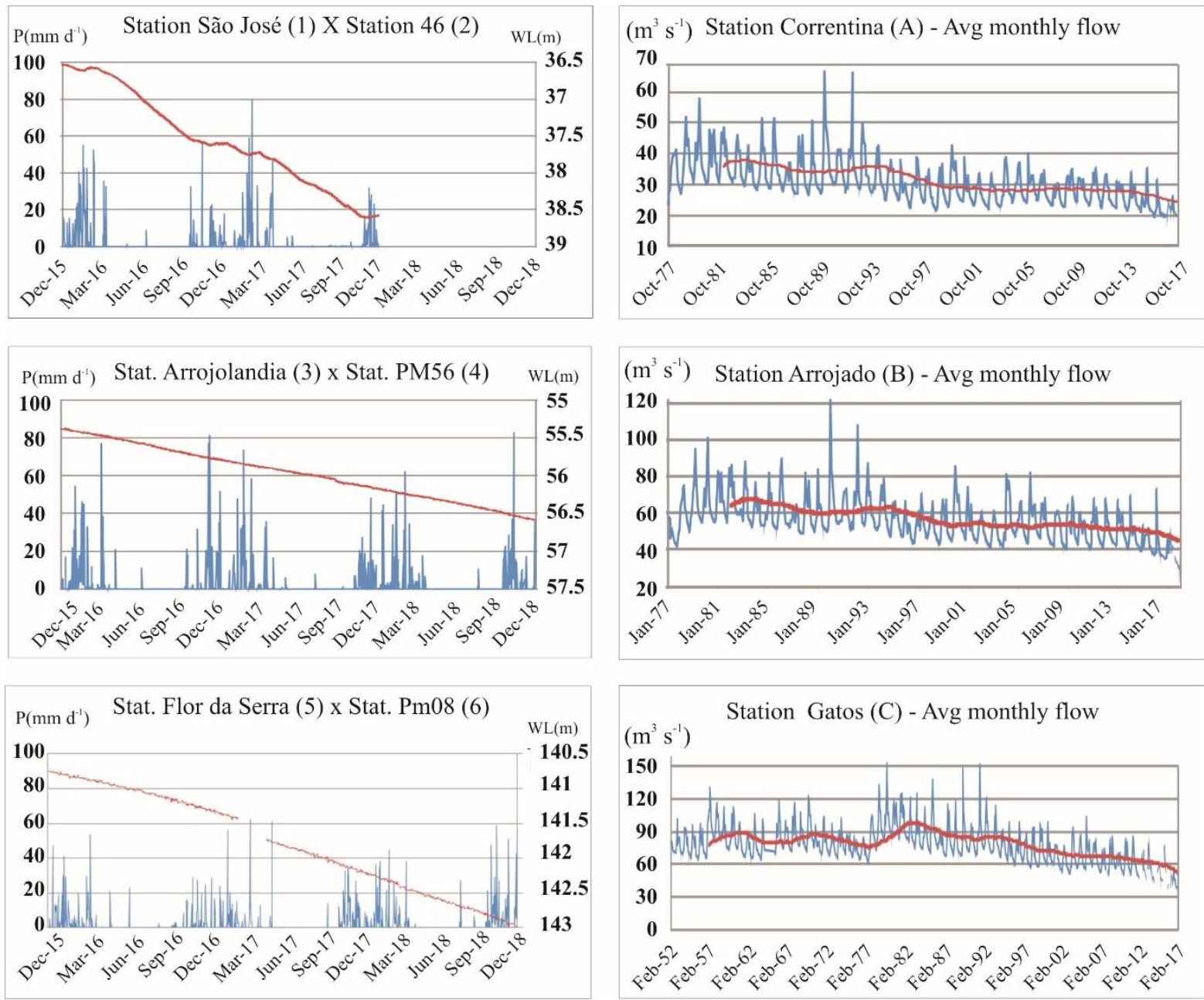

Figure 2. Variations of the water table in relation to precipitation in the region (the geographical position of the rainfall stations and wells are indicated by the corresponding numbers in Figure 1) and average monthly flows (blue) with 5-year moving averages (red) for each historical series in the river stations A- Correntina (Éguas River), B- Arrojado (Arrojado River) and C- Gatos (Formoso River). 
Surface drainage is characterized by parallel to subparallel river network, aligned according to generally N60E brittle structures, which carve a prairie, slightly sloping, with flattened top and altitudes ranging from 470 to $1016 \mathrm{~m}$. According to Ramos and Silva (2002), the entire river basin contributes approximately $160 \mathrm{~m}^{3} \mathrm{~s}^{-1}$ (of the minimum flows) to the São Francisco River, representing $15.6 \%$ of the total net discharge of the basin at Barra, São Francisco River.

The graphs of Figure 2 (A, B, C) represent the historical data of average monthly flows and average flows during 5-year periods of the Éguas, Arrojado and Formoso Rivers (ANA, 2019), showing a continuous decline since the 90 's. This can be potentially explained by the decrease in rainfall (Pousa et al., 2019) and by an increase in surface water intakes for agricultural purposes, including irrigation (the flow-rate granted in 2017 was approximately 28 $\mathrm{m}^{3} \mathrm{~s}^{-1}$ ). The other charts in Figure 2 shows the groundwater levels (WL) with respect to the ground surface (CPRM, 2019), compared to the rainfall (P) at the nearest station (ANA, 2019) (geographical position of the stations, see Figure 1).

\subsection{Pumping wells and monitoring data}

The preprocessing of the data was done in a Geographic Information System (GIS) environment using the ArcMap 10.2 program from ArcGis, where geological, geophysical, hydroclimatic and productive wells and monitoring data could be georeferenced. For the registered wells, data were obtained during field campaigns from this research, identified from the internal reports of the GSB (CPRM, 2008), and including data collection directly from landowners, drilling and granting data provided by the Institute of Environment and Water Resources (INEMA). The information obtained includes the geographic positioning of wells, the lithological and/or constructive profiles and the discharge data. For the majority of the wells, the rates of abstraction were inferred from the use or purpose of the property.

Data from eleven monitoring wells were obtained from the GSB Rede Integrada de Monitoramento de Águas Subterrâneas (RIMAS), where data loggers were installed from September 2015; however, not all have the same historical series, either because they started operating on different dates or because the reading was stopped for different reasons. The installed sensors (dipperlog and barlog) are HERON-branded and have been programmed to record barometric pressure and water-level depth data every hour. These wells served as observation wells for calibration in the simulations performed.

The increase of simulated pumping wells in scenario three is justified due to the economic potential of the region to develop agribusiness in irrigated areas.

\subsection{Geometry of the aquifer}

The thickness of the Urucuia aquifer is not yet a consensus in the literature, with maximum values between $300 \mathrm{~m}$ (ANA, 2013) and $1000 \mathrm{~m}$ (Bomfim and Gomes, 2004). Since it is a regional aquifer, the modeling of the aquifer base geometry, prior to flow simulation, was essential in the attempt to minimize errors. The geological modeling process of the Urucuia aquifer base was performed in Strat3D software (Version 2.1.75.0), that creates strata block tridimensional prism models. It started with the insertion of the database into the program environment, informing the spatial position of each drill hole (in this case, tubular well), as well as the height of the hole; lithology, stratigraphic unit and other descriptive characteristics of the lithological intervals of each hole and correlations were determined from the interpretations made by the software. The data inserted in the modeling of the base of the aquifer were: 2 stratigraphic wells; RIMAS network wells, tubular wells with lithological profile; 129 points of basement outcrops and basement/crystalline contact; and 12 virtual holes from scientific articles and seismic data from the area.

The next step was the definition of the stratigraphic order of the sedimentary packages 
according to the geological knowledge of the region and scientific works.

The arrangement of the data in 3D format allowed the visualization of the holes side by side through vertical sections, allowing the correlation between the strata recorded in each well. For the construction of the three-dimensional geological models, the Strat3D uses two distinct interpolators, one for the thickness and the other for the surfaces, generating top and base surfaces for each of the correlated layers. In this study, the nearest neighbor interpolation was used for both situations. The cell size used was $500 \mathrm{~m}$ horizontally and $10 \mathrm{~m}$ vertical. The closure of the solids was done based on the method of the areas of influence of each hole, which extends up to half the distance that separates it from the surrounding wells and also within the limits of established structural faultings. The generated geological models were based on the digital elevation model obtained from the Topographic Radar Shuttle Mission (TRSM) image, with a resolution of $30 \mathrm{~m}$.

\subsection{Numerical model}

According to Anderson and Woessner (1992), numerical models are used to represent the complexities of the physical environment, especially in situations where the application of analytical solutions is considered simplistic and inappropriate.

Among the numerical methods applied in groundwater modeling, the method used in this work (FDM) is to approximate the modeled area as a finite difference grid, where lines and columns define the grid of the model. Thus, in an iterative process, the differential equations of flow are processed, and the hydraulic heads are calculated. The code used was the ModularThree-Dimensional Finite-Difference Groundwater Flow (MODFLOW), developed by the U.S. Geological Survey (Harbaugh et al., 2000; McDonald and Harbaugh, 1988) using VisualModflow software, V.4.1. The Solver applied to run the program was the WHS, for unconfined aquifers, using the default convergence parameters.

The grid discretization was 182 rows by 267 columns, resulting in 48,594 active cells, with widths ranging from $380 \times 380 \mathrm{~m}$ to $780 \times 780 \mathrm{~m}$ and the greatest refinement in the areas near the pumping and observation wells. The grid cells outside the model boundaries are assigned as inactive cells, such that they are not used in calculating head.

The boundary conditions were as follows: no flow (Newman) lower boundary representing impervious aquifer base; constant head (Dirichlet) eastern boundary representing iso piezometric line at $627 \mathrm{~m}$; no flow northern and southern boundaries representing topografic divides; no flow western boundary representing a groundwater divide; and head dependent flux boundaries (Cauchy) representing the Éguas, Arrojado, Pratudão and Formoso Rivers (Figure $1)$.

Aquifer recharge was conceived in four zones based on average measured rainfall at available stations and resulting isohyets (Bahia, 1998). For each zone, recharge was estimated as $17 \%$ (based on Meyboom method, CPRM, 2008) of the annual mean precipitation, giving values of 176 to $208 \mathrm{~mm}_{\text {year }}{ }^{-1}$.

The hydraulic conductivity of the aquifer and river conductance were used as calibration parameters with respect to observed hydraulic heads. In the calibration process, hydraulic conductivity was varied from $10^{-7}$ to $10^{-4} \mathrm{~m} \mathrm{~s}^{-1}$ which is the range of values observed in aquifer tests performed in the study area and in the nearby northern Urucuia aquifer (Gaspar, 2007; CPRM, 2008). Data on riverbed geometry and conductivity per cell are not available. Alternatively, we decided to use conductance as a second calibration parameter whose value was varied from $0.0058 \mathrm{~m}^{2} \mathrm{~s}^{-1}$ to $1.1 \mathrm{~m}^{2} \mathrm{~s}^{-1}$. These limits approximately correspond to the extreme situations, where the rivers are effectively disconnected from and perfectly connected to the aquifer, respectively. The same conductance is justified because the rivers of the region have similar physiographic features and the vertical hydraulic conductivity of the riverbed must be very close in all its length due to the homogeneity of the geology. 
Three steady-state scenarios are considered for numerical simulation: i) the natural hydrological system, without anthropic influence of pumping wells; (ii) including wells operating at current (2017) withdrawal rates; and (iii) with a fictitious pumping scenario of 60 additional wells at a flow rate of $4000 \mathrm{~m}^{3}$ day $^{-1}$ (60\% increase over current pumping) spaced throughout the modeled area, but maintaining a minimum distance of $5 \mathrm{~km}$ from other wells and more than $2 \mathrm{~km}$ from the rivers.

Overall, the modeled aquifer system receives water inflow from recharge due to spatially distributed precipitation, in addition to infiltration from limited river portions. Outflow consists of well extraction, leakage into rivers and the underground flow across the eastern constant head boundary.

It is important to highlight the assumptions and limitations of the model: i) The zero-flow assumption at the base of the layer is based on geological studies and geophysical surveys, but there may be some location in the basin where the lithopost Bambui Group lithology allows hydraulic connection to the Urucuia aquifer; ii) there is a low degree of uncertainty in the value and positioning of the boundary condition constant head, which was obtained from potentiometric maps made between 2005 and 2009; iii) terrain elevation data are satisfactory for regional analysis; iv) the aquifer is considered regionally unconfined, but non-mappable silicified sandstone facies can occur locally, giving the aquifer a confined or semi-confined character; and v) the observed aquifer heads (e.g. Figure 2) are highly transient and average heads are used for calibration of the present steady-state model.

\section{RESULTS AND DISCUSSION}

\subsection{Survey of pumping well rates}

Among the 323 registered wells in the study area, 282 are contained inside the modeling domain. It is observed that only about $30 \%$ of the wells have a grant (data up to 2016). Among the wells granted, $52 \%$ are for irrigation, $22 \%$ for human supplies, $12 \%$ for animal husbandry, $7 \%$ for industrial use, and 5\% for public use. The irrigated crops are bermuda grass, cotton, beans, corn, coffee and soybeans.

Table 1 presents the main characteristics of the pumping- and observation wells, and Figure 1 shows the distribution of the wells in the study area.

Table 1. Data from wells surveyed and included in the model.

\begin{tabular}{|c|c|c|c|c|c|c|c|c|c|c|c|c|}
\hline \multirow{2}{*}{ Well } & \multicolumn{3}{|c|}{ Depth (m) } & \multicolumn{3}{|c|}{$\mathrm{WL}(\mathrm{m})$} & \multicolumn{4}{|c|}{$\mathrm{Q}\left(\mathrm{m}^{3} \mathrm{~h}^{-1}\right)$} & \multicolumn{2}{|c|}{$\mathrm{Q}_{\mathrm{s}}\left(\mathrm{m}^{3} \mathrm{~h}^{-1} \mathrm{~m}^{-1}\right)$} \\
\hline & $\min$ & mean & $\max$ & $\min$ & mean & $\max$ & $\min$ & mean & $\max$ & $\min$ & mean & $\max$ \\
\hline Pumping Wells (323) & 30 & 126 & 290 & 17 & 64 & 150 & 1 & 29 & 560 & 0.97 & 12.97 & 48.68 \\
\hline Monitoring Wells (11) & 68 & 114 & 180 & 36 & 73 & 138 & 8.5 & 11 & 13.2 & 0.53 & 2.32 & 6.29 \\
\hline
\end{tabular}

*WL= Water level below local ground surface; $\mathrm{Q}=$ Pumping Rate; $\mathrm{Qs}=$ Specific capacity (ratio between pumping rate and drawdown).

The sum of the pumping rates at all wells in the study area for 2017 was $4.61 \mathrm{~m}^{3} \mathrm{~s}^{-1}(3.37$ $\mathrm{m}^{3} \mathrm{~s}^{-1}$ for the modeled area), and it is observed that $26.8 \%$ of the water exploited by the wells is positioned in the portion of the aquifer that drains to the West and not considered herein. The highest-flow wells are generally wells for irrigation and are granted to exploit between 20 to $500 \mathrm{~m}^{3} \mathrm{~h}^{-1}$ for 4 to $24 \mathrm{~h} \mathrm{day}^{-1}$ (representing about $20 \%$ of the wells granted).

It is important to emphasize the need for implementation and access to continuous measurements of water levels and flow rates in production wells, especially where extraction rates are large. 


\subsection{Geometry of the aquifer (base mapping)}

The result of the geometric modeling of the Urucuia aquifer allows identifying a sedimentary basin of intracontinental "sag" type with small subsidence (maximum thickness of approximately $500 \mathrm{~m}$ ). Figure 3 contains two different representations to illustrate the thickness of the Urucuia aquifer.

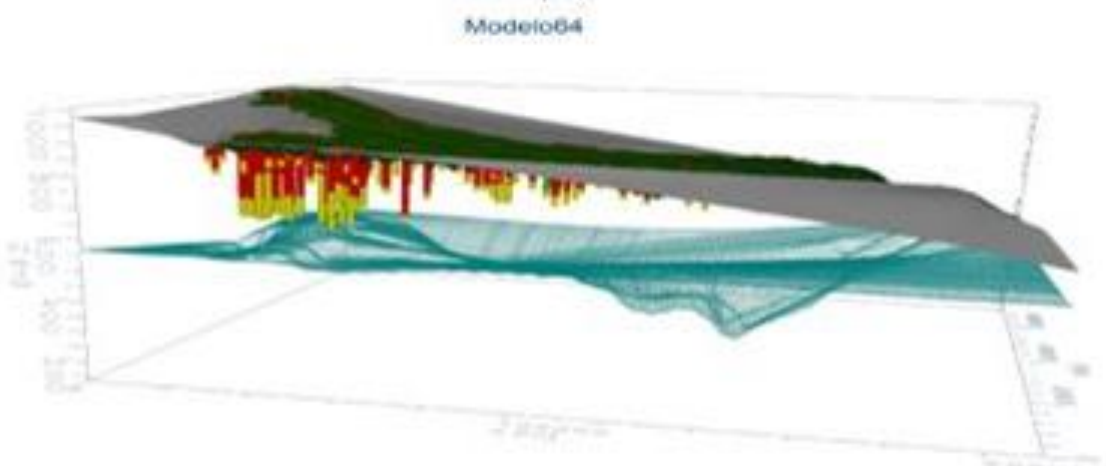

B)

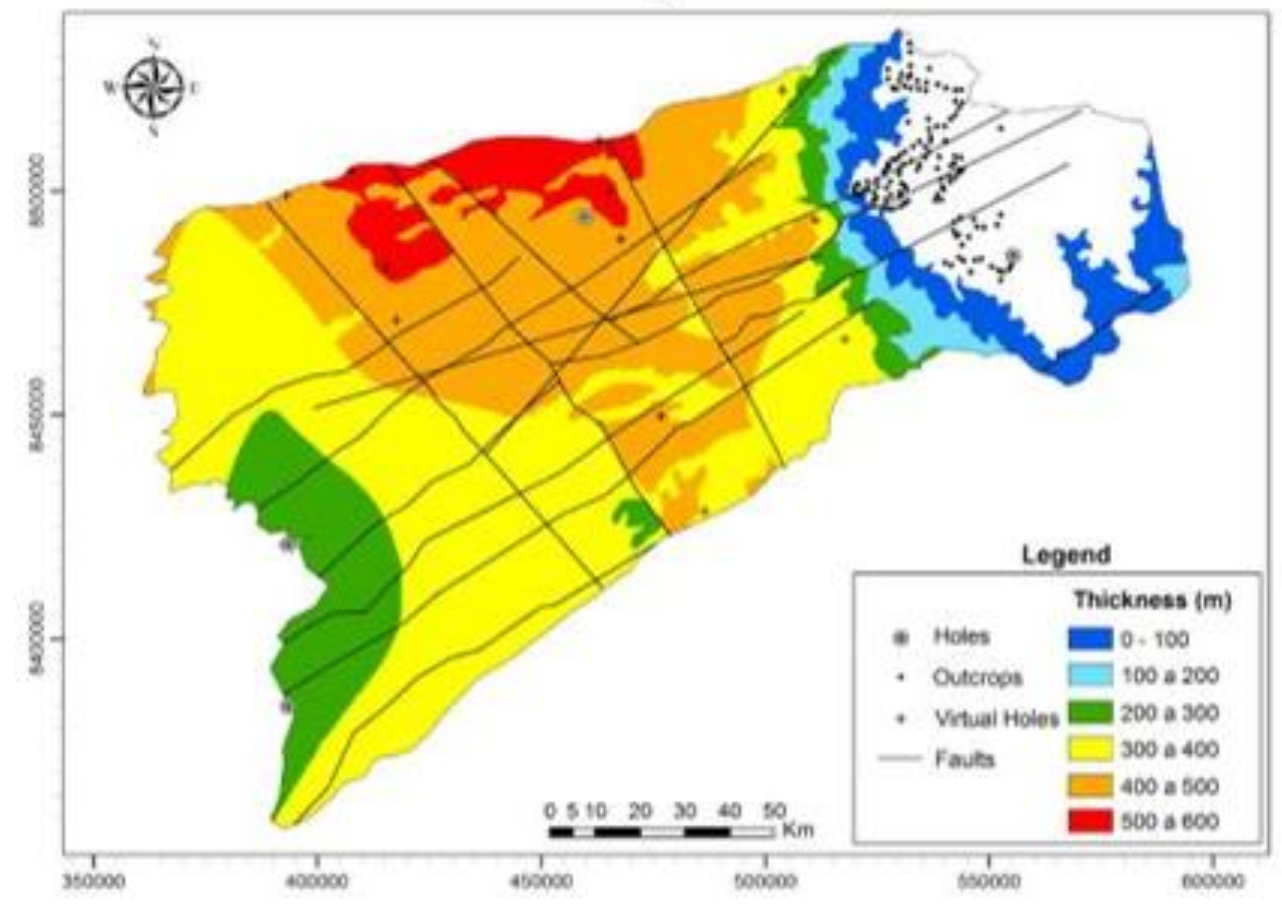

Figure 3. A) 3D model of the UAS base (green surface) with the productive tubular wells (yellow/red), 60x vertical exaggeration. B) Map of thickness of Urucuia aquifer.

It is noticed that the surface of the UAS base presents a greater thickening in the western border in relation to the east border, and tends to be thicker in the north center portion (Figure $3)$.

The thicknesses of the modeled aquifer represents the UAS, consisting of sedimentary rocks, predominantly sandy, with small-scale lithological heterogeneities (silicified zones, pelitic and/or conglomerate horizons). These discontinuities are considered to be negligible for the regional flow dynamics, such that the system is defined here regionally as a single isotropic and homogeneous hydrostratigraphic unit with thicknesses ranging from 160 to $535 \mathrm{~m}$. There is no evidence that failure systems can form hydraulic flow barriers. 


\subsection{Aquifer modeling: Flow simulation and mass balance}

The calibration process consisted in varying the river conductance and hydraulic conductivity, in order to obtain the best hydraulic head distribution in terms of smallest differences between simulated (using 2017 pumping scenario) and observed hydraulic heads at 11 observation wells, considering the Root Mean Squared (RMS) Normalized (\%) values as an evaluation parameter (modeling quality indicator). Table 2 shows the RMS residuals for the three simulated pumping scenarios.

Table 2. Calculated RMS and correlation coefficients for the three simulations. Scenario 1 (Without pumping); Scenario 2 (with current pumping) and Scenario 3 (current pumping increased by $60 \%)$.

\begin{tabular}{lcccc}
\hline & \multicolumn{2}{c}{ Scenario 1 } & \multicolumn{2}{c}{ Scenarios 2 and 3 } \\
\hline Number of observation wells & 11 & 9 & 11 & 9 \\
RMS (m) & 25.6 & 18.0 & 25.6 & 18.3 \\
Normalized RMS (\%) & 14.7 & 10.3 & 14.7 & 10.5 \\
Correlation Coefficient (\%) & 95.3 & 98.5 & 94.6 & 98.1 \\
\hline
\end{tabular}

The values of RMS are closer to the acceptable value in the literature (10\%) when the PM08 (Prata Farm) and PM54 (Assentamento) monitoring wells are removed from the evaluation, and present fairly close values for the two situations. Possibly the largest sources of inaccuracy are related to terrain altimetry data in the discretized grid of the model.

The values presented are the result of the simulations with the calibrated parameters of hydraulic conductivity of $6 \times 10^{-4} \mathrm{~m} \mathrm{~s}^{-1}$ and conductance of $2.3 \times 10^{-2} \mathrm{~m}^{2} \mathrm{~s}^{-1}$. The calibration process showed that model performance is more sensitive to the hydraulic conductivity and less sensitive to the river conductance values.

With these calibrated values, the simulations with and without pumping were run using the same recharge rate of $87.15 \mathrm{~m}^{3} \mathrm{~s}^{-1}$, resulting in the partitioning of the other components of the water balance, according to Table 3. It is observed that the rivers are predominantly discharge zones, with base flow in the range of $85 \mathrm{~m}^{3} \mathrm{~s}^{-1}$, approximately $68 \%$ of the sum of the three rivers' minimum discharges.

Table 3. Mass balances of the simulations with and without pumping.

\begin{tabular}{lccccc}
\hline & \multicolumn{2}{c}{ Inflow $\left(\mathbf{m}^{\mathbf{3}} \mathbf{s}^{\mathbf{- 1}}\right)$} & \multicolumn{3}{c}{ Outflow $\left(\mathbf{m}^{\mathbf{3}} \mathbf{s}^{\mathbf{- 1}}\right)$} \\
\cline { 2 - 6 } & Recharge & River leakage & Pumping well & River leakage & Constant Head \\
\hline Without Pumping & 87.15 & 28.28 & 0 & 89.54 & 25.86 \\
Current Pumping (2017) & 87.15 & 26.44 & 3.37 & 83.91 & 26.30 \\
Fictitious Pumping & 87.15 & 27.02 & 5.4 & 81.80 & 26.22 \\
\hline
\end{tabular}

It should be noted that the simulated mass balances do not include anthropogenic withdrawals of surface waters. The mass balances still show that the base-flow of the three main rivers in the study area decreases from $89.54 \mathrm{~m}^{3} \mathrm{~s}^{-1}$ in the non-pumping situation to $83.91 \mathrm{~m}^{3} \mathrm{~s}^{-}$ ${ }^{1}$ with current pumping (approximately $6 \%$ reduction due to pumping).

The maps presented in Figure 4 show the distributions of hydraulic heads, that is, the potentiometric maps for the three simulations. The main flow direction is SW-NE, with drainage (main rivers) acting as discharge area of the aquifer, being more pronounced in the Arrojado and Formoso Rivers. The potentiometric map in the current pumping situation presents overall features very close to the natural situation. However, in the western region there is a displacement of the potentiometric curve of $840 \mathrm{~m}$ to the north and $870 \mathrm{~m}$ to the south. 
(A)

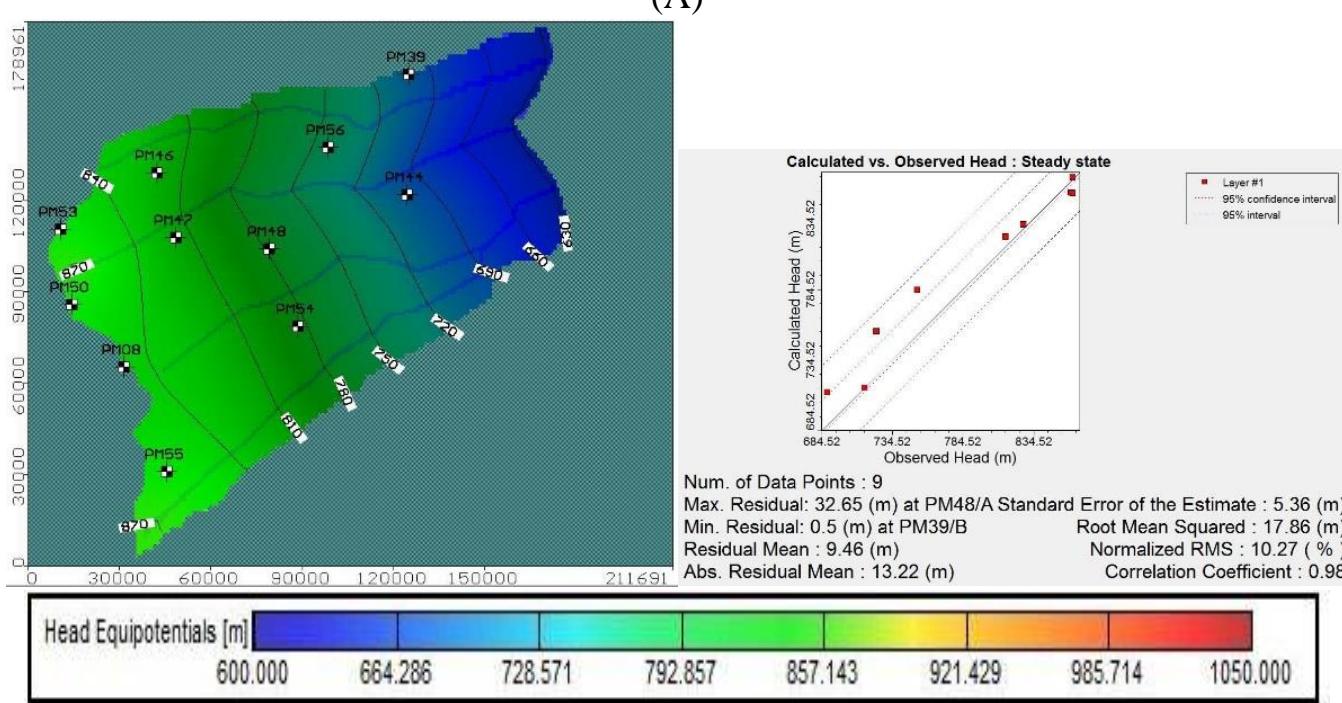

(B)
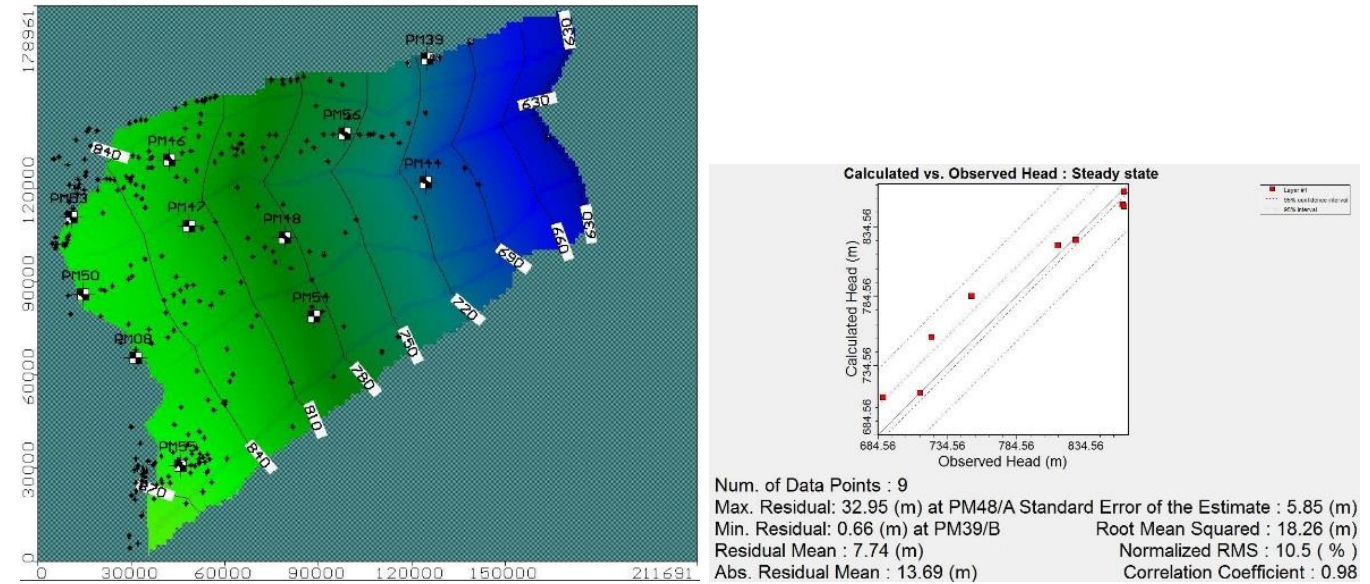

Num. of Data Points : 9

Max. Residual: $32.95(\mathrm{~m})$ at PM48/A Standard Error of the Estimate : $5.85(\mathrm{~m})$ Min. Residual: $0.66(\mathrm{~m})$ at PM39/B Root Mean Squared : $18.26(\mathrm{~m})$ $\begin{array}{ll}\text { Residual Mean : } 7.74(\mathrm{~m}) & \text { Normalized RMS : } 10.5(\%) \\ \text { Abs. Residual Mean : } 13.69(\mathrm{~m}) & \text { Correlation Coefficient : } 0.98\end{array}$

\begin{tabular}{|c|c|c|c|c|c|c|c|}
\hline \multicolumn{8}{|l|}{ Head Equipotentials $[\mathrm{m}][$} \\
\hline 600.000 & 670.588 & 741.177 & 776.471 & 855.882 & 900.000 & 979.412 & 1050.000 \\
\hline
\end{tabular}

C)

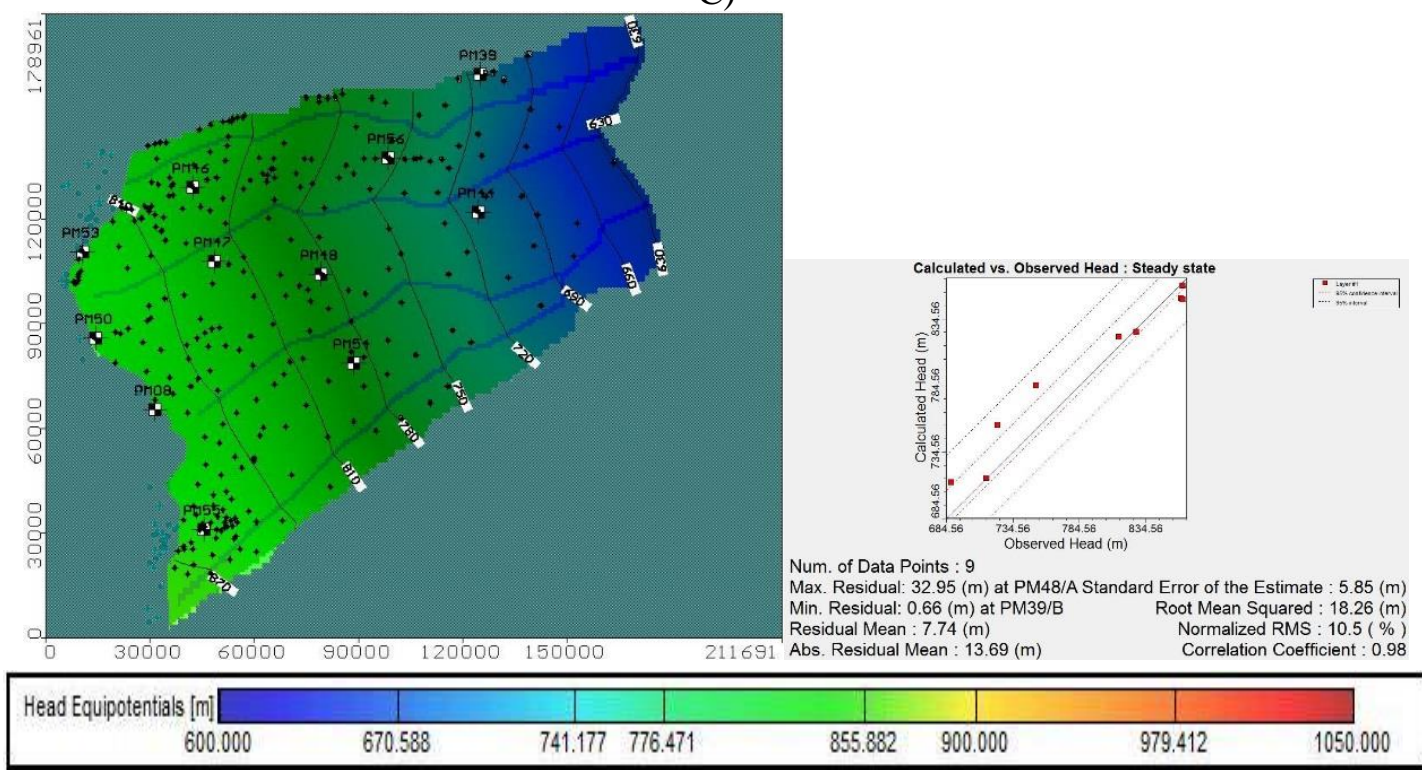

Figure 4. Potentiometric maps with groundwater flow from simulations and their respective graphs of observed- versus simulated hydraulic heads: A) no pumping; B) with pumping, relative to the year 2017 ; C) fictitious well pumping increased by $60 \%$. 
Figure 5 provides a better view of the drawdown due to pumping by showing the differences between hydraulic heads without and with pumping in 2017. Regions with high pumping rates are correctly identified as the most-impacted (green to red). Based on this map, we calculated an average aquifer drawdown of $0.8 \mathrm{~m}$. Considering an average effective porosity of $15 \%$, this corresponds to a variation of groundwater storage volume (depletion) between stationary conditions without pumping and with pumping of approximately $2.0 \mathrm{~km}^{3}$.

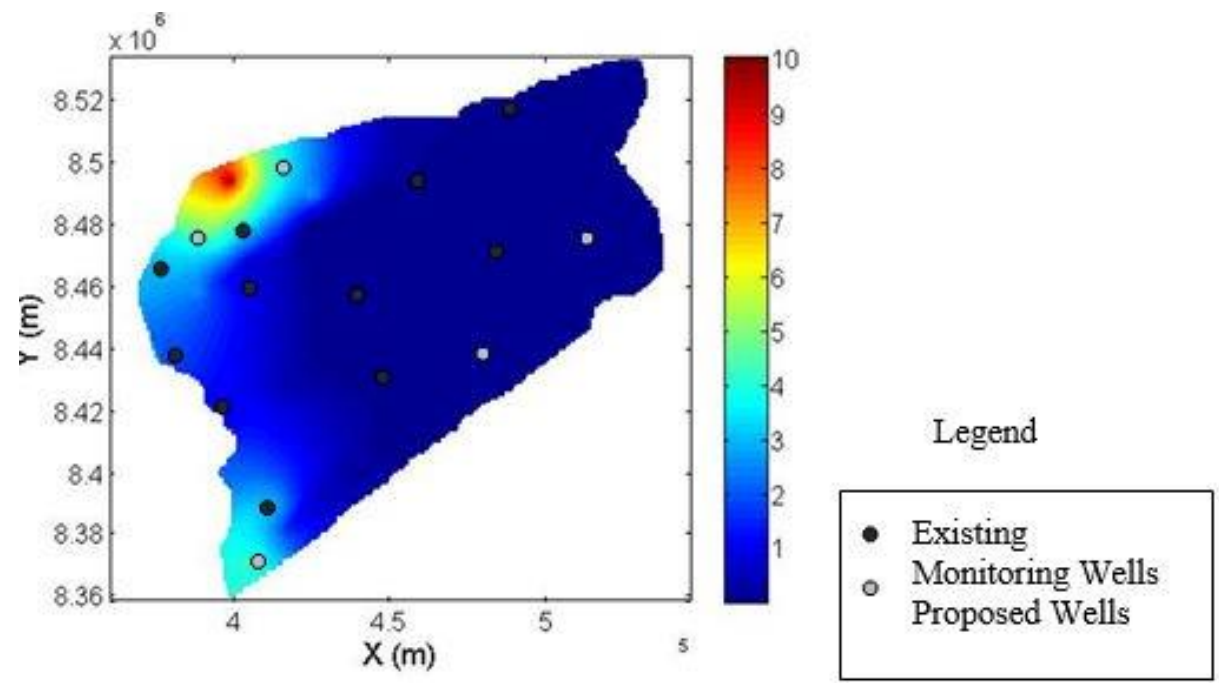

Figure 5. Map of hydraulic head differences (drawdown) without and with pumping (base year 2017). Monitoring well and additional monitoring wells proposed at approximate locations where data is scarcest and/or drawdown are largest.

There will probably be an expansion of the network of productive wells in the region, due to socioeconomic and land-use characteristics of the area. This reinforces the importance of continuous monitoring of water levels at monitoring wells for compiling more-complete historical series of data to update and expand existing modeling studies.

A well-designed network of monitoring wells may also provide information towards defining boundary conditions (hydraulic heads) for the modeling of smaller areas with greater accuracy. New observation wells positioned at the approximate locations shown in Figure 5 are suggested to improve the network monitoring in areas where data is scarcest (lowest level of information) and areas where drawdowns are largest (highest impact). Moreover, monitoring wells can also be installed at the western border of the modeled area to better define the groundwater divider.

\section{CONCLUSIONS}

The simulation of flow and the mass balance from numerical modeling proved to be a useful tool to quantify the interference of pumping activities in hydrological systems in general.

In the hydrographic basins that correspond to the modeled area of the present study, the results demonstrate that the aquifer does not suffer significant variations in the main direction of regional flow due to the pumping; however the unequal distribution of the wells and the concentration of high flow wells in some points can contribute to localized flow inversions.

The effects of groundwater extraction on river base flows are due to decreasing groundwater storage and the related regional drawdown. This emphasizes the importance of continuous monitoring of aquifer water levels and well-pumping rates as well as a continuous updating of hydrological modeling efforts to maintain sustainable agricultural development. The study of the transient-state simulation of the study area is suggested. 


\section{ACKNOWLEDGMENTS}

We thank to Geological Survey of Brazil for logistical to support this work.

\section{REFERENCES}

AGÊNCIA NACIONAL DE ÁGUAS (Brasil). Sistema Nacional de Informações sobre Recursos Hídricos. Brasília, 2019. Available at: http://www.snirh.gov.br/hidroweb/publico/medicoes_historicas_abas.jsf. Access: 21 Jan. 2019.

AGÊNCIA NACIONAL DE ÁGUAS (Brasil). Estudos hidrogeológicos e de vulnerabilidade do sistema Aquífero Urucuia e proposição de modelo de gestão integrada e compartilhada. Brasília, 2013. v. 1. 72p.

AGÊNCIA NACIONAL DE ÁGUAS (Brasil). Conjuntura dos Recursos Hídricos no Brasil 2018: informe anual. Brasília, 2018. 72p. Available at: www.snirh.gov.br/portal/snirh/centrais-de-conteudos/conjuntura-dos-recursoshidricos/informe-conjuntura-2018.pdf. Access: 21 Jan. 2019.

ASSOCIAÇÃO DE AGRICULTORES E IRRIGANTES DA BAHIA. Anuário da Safra do Oeste Baiano 2017/2018. Barreiras, 2019. Available at: http://aiba.org.br/wpcontent/uploads/2019/06/Anuário-2019-Português-Digital.pdf. Access: 02 Aug. 2019.

ANDERSON, M. P.; WOESSNER, W. W. Applied groundwater modeling: simulation of flow and advective transport. San Diego: Academic Press, 1992. 381p.

BAHIA. SEI. Análise dos atributos climáticos do Estado da Bahia. Salvador, 1998. 85p.

BOMFIM, L. F. C.; GOMES, R. A. D. Aquífero Urucuia: Geometria e espessura: ideias para discussão. In: CONGRESSO BRASILEIRO DE ÁGUAS SUBTERRÂNEAS, 8., 2004, Cuiabá-MT. Anais [...] Cuiabá: ABAS, 2004.

BRAGANÇA, A. The economic consequences of the agricultural expansion in MATOPIBA. Revista Brasileira de Economia, v. 72, n. 2, 2018. http://dx.doi.org/10.5935/00347140.20180008

CAMPOS, J. E. G.; DARDENNE, M. A. A glaciação Neopaleozóica na porção meridional da Bacia Sanfranciscana. Revista Brasileira de Geociências, v.24, n.2, p.65-76, 1994.

CAMPOS, J. E. G.; DARDENNE, M. A. Estratigrafia e Sedimentação da Bacia Sanfranciscana: Uma Revisão. Revista Brasileira de Geociências, v.27, n.3, p.269-282, 1997.

CPRM. Hidrogeologia do aquífero Urucuia - Bacias dos Rios Arrojado e Formoso, Bahia. Brasília: CPRM/UFBA/FINEP, 2008. 1 CD-ROM.

CPRM. RIMAS. Brasília, 2019. Available at: http://rimasweb.cprm.gov.br/layout/pesquisa_complexa.php?rimas=true. Access: 22 May 2019.

ENGELBRECHT, B. Z.; CHANG, H. K. Simulação numérica de fluxo de águas do Sistema aquífero Urucuia na Bacia Hidrogeológica do rio Corrente (BA). Revista Águas Subterrâneas, v.29, n.2, p.244-256, 2015. https://doi.org/10.14295/ras.v29i2.28435

FREEZE, R. A.; CHERRY, J. A. Groundwater. Englewood Cliffs: Prentice Hall, 1979. 604p.

GASPAR, M. T. P.; CAMPOS, J. E. G. O Sistema Aquífero Urucuia. Revista Brasileira de Geociências, v.37, n.4, p.216-226, 2007.

Rev. Ambient. Água vol. 14 n. 6, e2390 - Taubaté 2019 
GONÇALVES, R. D.; CHANG, H. K. Modelo Hidrogeológico do aquífero Urucuia na bacia do rio Grande (BA). Revista Geociências, v.36, n.2, p.205-220, 2017. http://orcid.org/0000-0002-3088-1000

FERRARINI, A. D. S. F.; FERREIRA-FILHO, J. B. S.; HORRIDGE, M. Water demand prospects in Brazil: a sectoral evaluation using an inter-regional CGE MODEL1. In: ANNUAL CONFERENCE ON GLOBAL ECONOMIC ANALYSIS, 19., 2016, Washington. Conference Paper[...] Washington: Gtap, 2016.

HAQUE, M. A. M.; JAHAN, C. S.; MAZUMDER, Q. H.; NAWAZ, S. M. S.; MIRDHA, G. C.; MAMUD, P.; ADHAM, M. I. Hydrogeological condition and assessment of groundwater resources using visual modflow, modeling, Rajshahi City Aquifer, Bangladesh. Journal of the Geological Society of India, v.79, n.1, p.77-84, 2012. https://doi.org/10.1007/s12594-012-0001-7

HARBAUGH, A. W.; BANTA, E. R.; HILL, M. C.; McDONALD, M. G. Modflow-2000, The U.S. Geological Survey modular groundwater model - User Guide to Modularization concepts and the groundwater flow process. Washington: USGS, 2000. 130p.

McDONALD, M. G.; HARBAUGH, A. W. A modular three-dimensional finite-difference groundwater flow model. Reston: USGS, 1988. 586p.

MIRANDA, E.; MAGAlHÃES, L.; CARVALHO, C. A. Proposta de delimitação territorial do MATOPIBA. Campinas: Embrapa, 2014. Available at: https://www.embrapa.br/gite/publicacoes/NT1_DelimitacaoMatopiba.pdf. Access: 7 May 2019.

NOGUEIRA, D. Brasil tem um conflito por água praticamente a cada dois dias. O Globo, Rio de Janeiro, 2018. Available at: https://oglobo.globo.com/brasil/brasil-tem-um-conflitopor-agua-praticamente-cada-dois-dias-22509460. Access: 5 May 2019.

OLIVEIRA, M. A. B. Do Sertão São Francisco ao Oeste na Bahia: uma análise da trajetória de políticas do Estado no processo de formação territorial (1889-2014). 2015. $262 \mathrm{f}$. Dissertação (Mestrado) - Instituto de Geociências, Universidade Federal da Bahia, Salvador, 2015.

POUSA, R.; COSTA, M. H.; PIMENTA, F. M.; FONTES, V. C.; BRITO, V. F. A.; CASTRO, M. Climate change and intensive irrigation growth in western Bahia, Brazil: the urgent need for hydroclimatic monitoring. Water, v.11, n.5, p.933, 2019. https://doi.dx.org/10.3390/w11050933

RAMOS A. M.; SILVA F. F. Contribuição dos mananciais superficiais do Estado da Bahia para o Rio São Francisco. In: SIMPÓSIO DE RECURSOS HÍDRICOS DO NORDESTE, 6., 2002, Maceió-AL. Anais[...] Maceió: ABRH, 2002. 1 CD-ROM.

SAHOO, S.; JHA, M. K. Numerical groundwater flow modeling to evaluate potential effects of pumping and recharge: implications for sustainable groundwater management in the Mahanadi delta region, India. Hydrogeology Journal, v.25, n.8, p2489-2511, 2017. https://doi.org/10.1007/s10040-017-1610-4

SANTOS, C. D. Difusão do agronegócio e reestruturação urbano-regional no Oeste Baiano. Geotextos, v.12, n.1, 2016. http://dx.doi.org/10.9771/1984-5537geo.v12i1.15381 
SANZ, D.; CASTAÑO, S.; CASSIRAGA, E.; SAHUQUILlO, A.; GÓMEZ-ALDAY, J.; PEÑA, S.; CALERA, A. Modeling aquifer-river interactions under the influence of groundwater abstraction in the Mancha Oriental System (SE Spain). Hydrogeology Journal, v.19, n.2, p.475-487, 2011. https://doi.org/10.1007/s10040-010-0694-X

SARAIVA, R. Guerra pela água em Correntina se arrasta desde 2015. Correio 24 Horas, Salvador, 2017. Available at: https://www.correio24horas.com.br/noticia/nid/guerrapela-agua-em-correntina-se-arrasta-desde-2015/. Access: 6 May 2019.

SCHUSTER, H. D. M. Modelagem de fluxo subterrâneo com vistas à definição de parâmetros para outorga de mananciais subterrâneos na bacia hidrográfica do Rio do Cachorro: oeste do Estado da Bahia. Salvador: [S.n], 2003a. 125p.

SCHUSTER, H. D. M. Modelagem de fluxo subterrâneo com vistas à definição do distanciamento entre poços e mananciais no Oeste Baiano: Relatório Final. Salvador, DMG/UFCG/CCT, 2003b. 42p.

SCHUSTER, H. D. M.; CRUZ, J. L. F.; SILVA, F. F. Modelagem do efeito de bombeamento na depleção de rios. Parte 2: simulações de um caso real no Oeste da Bahia. In: SIMPÓSIO DE RECURSOS HÍDRICOS DO NORDESTE, 10,, 2010, Fortaleza-CE. Anais[...] Fortaleza: ABRH, 2010. 1 CD-ROM.

SUPERINTENDÊNCIA DE RECURSOS HÍDRICOS DO ESTADO DA BAHIA. Uso Conjunto das águas superficiais e subterrâneas da sub-bacia do rio das Fêmeas Bahia. Salvador: SRH, 2003. 166p.

SWITZMAN, H.; COULIBALY, P.; ZAFAR, A. Modeling the impacts of dryland agricultural reclamation on groundwater resources in Northern Egypt using sparse data. Journal of Hydrology, v.520, p.420-438, 2015. https://doi.org/10.1016/j.jhydrol.2014.10.064

UNESCO. Global water resources under increasing pressure from rapidly growing demands and climate change: according to new UN World Water Development Report. In: UNITED NATIONS WORLD WATER ASSESSMENT. Programme[...] Washington, 2012. WWDR4 - Background Information Brief. Available at: http://www.unesco.org/new/fileadmin/multimedia/hq/sc/pdf/WWWDR4\%20Backgroun d\%20Briefing\%20Note_ENG.pdf. Accessed on: 22 jan. 2019.

WERNER. A. D.; ZHANG, Q.; XUE, L.; SMERDON, B. D.; LI, X.; ZHU, X.; YU, L.; LI, L. An initial inventory and indexation of groundwater mega-depletion cases. Water Resources Management, v.27, n.2, p.507-533, 2013. https://doi.org/10.1007/s11269012-0199-6 